P1073

\title{
難分解性化学物質に対する生体試料バンクの有用性検証と 䀧露評価
}

\author{
吉永 㑆夫 ${ }^{1}$ 、原田 浩二 ${ }^{1}$ 井上 佳代子 ${ }^{1}$ 、難分解性物質 研究グループ* ${ }^{1} 、$ 小 \\ 泉 昭夫 ${ }^{1}$ \\ ${ }^{1}$ 京都大学大学院 医学研究科 環境衛生学分野
}

【はじめに】環境中に放出されて多種多様の化学物 質による環境污染や人体への影響を監視しするため に、私達は難分解性化学物質を対象としだ生体試料 バングを設立した。今回このバンクの試料を用いて、 バンクの有用性の証明と、新規物質の曝露評価を行 つた。方法] 約 30 年前から収集された生体試料 (血 波と陰膡方式の食事) と新規に全国で 10 筒所で集め 出した武料（血液、母乳と購入方式の食事）を基に 血液 24,500 、母乳 1,080 、食事 3,800 検体から成るバ ンクを創設した。これらの試料から 1980 年代、1995 年代を中心とした、同一人物からセットで提供され た血液と食事検体を用いて、GC/MS 法 (有機溶剂抽 出法) で\#74、\#118、\#99、\#138、\#146、\#153、 \#163\&164、\#156、\#170、\#180、\#182\&187の コンジェナーの PCB を、原子吸光法 (僄元気化法) でメチル水銀を測定して既報のデータと比較てバン クの有用性を検討した。また新規化合物として、 PBDEs を GC/MS 法 (有機溶郕抽出法) で低-中臭 化の、\#47、\#100、\#99、\#153 のコンジェナ-を、 PFOS、PFOA を固相抽出して LS/MS 法で測定して ヒトの曝露評価を行った。結果】 PCBs : 血清中の 総 PCB は全国的に減少する傾向があり、年代的にコ ンジェナ-によっては有意の差があった。血清 PCB $\mathrm{s}$ の変動に与える要因として居住地域を有意な要因 で、地域的には北海道、関東地方で有意に低く、四 国、九州、中国で高かった。既報に反してより BMI の低いものに PCBs レベルが高い傾向が認められた。 メチル水銀：血中メチル水銀には年戟依存性か諗め られ、20 歳代から 60 歳代にかけて年齢ともに增加 する傾向があった。JECFA の新PTWI に対しては年 龄による変動の幅は $121.8 \sim 187.6 \%$, 地域により 90.5 〜324.3\%の範囲にあり、全体の平均は $157.8 \%$ とな った。血中メチル水銀濃度は地域差が大きく基準值
を越える地域があった。血中と食事検体のメチル水 銀の相関が強かった。PBDE s：1980 年でも全国で PBDE s の污染は認められたが、 8 ケ所中 6 ヶ所の地 域で幾何平均值は lng/g lipid 以下であった。1995 年 では、 3 力所に減少している。関東地域を除き、15 年間で数倍の増加を見ている。中国地域でこの 15 年間に血清濃度が 58.3 倍の增加が観られた。コンジ エナ-別では\#47 と\#99 の污染が進んでいることが 解った。PFOS、PFOA：血中の PFOA は経年的に增 加がしており、PFOA 濃度は女性より男性の方が高 かった。関西での污染が顕著で污染地域への移転後 2 年程度で高くなることが明らかになった。[考察] PCB、メチル水銀の測定結果から本バンクは有用性 が証明された。現在、母乳を含めた 2003 年代の検体 につき測定中であり、高臭化型の PBDEs の湘定の ために検体を提供中である。*本研究は更生労働科 学研究補助金 "POPS のリスク評洒にむけてのヒト 嚗露長期モニタリングのための試料バンクの創設に 関する研究” の一部である。班員 : 大前和幸（磨應 義塾大学)、日下幸則 (福井医科大学)、竹下達也 (和 歌山県立医科大学)、村田勝敬 (秋田大学医学部) 甲 田茂樹 (高知医科大学)、等々力英美 (琉球大学)、 和田安彦 (兵庫医科大学)、竹中勝信 (高山赤十字病 院)、渡辺孝男 (宮城教育大学)、中塚晴夫 (宮城大 学)、鴐藤憲光（岩手県環境保健センター）、藤峰磨 徳 (大塚製薬)、蜂谷紀之 (環境省国立水俣病総合研 究センター)、藤井滋穂 (京都大学) との共同研究で ある。 